\title{
PSA RNA-Pulsed Dendritic Cell Vaccine
}

National Cancer Institute

\section{Source}

National Cancer Institute. PSA RNA-Pulsed Dendritic Cell Vaccine. NCI Thesaurus. Code C2236

An autologous dendritic cell vaccine with potential immunostimulatory activity. Dendritic cells harvested from a prostate cancer patient are transfected with the mRNA encoding for prostate specific antigen (PSA), a tumor marker secreted by prostatic epithelial and ductal cells. When reintroduced back to the patient, these PSA RNA pulsed autologous dendritic cells may elicit a cytotoxic T-cell (CTL) response against PSA-positive prostate cancer cells. 